\title{
LOCAL POLITICS AND VIOLENT CRIME IN U.S. CITIES*
}

\author{
Thomas D. Stucky \\ Assistant Professor \\ Indiana Purdue University- Fort Wayne
}

June 2003

\begin{abstract}
*This research was supported by a National Science Foundation dissertation improvement award (\#SES-0002291), and the Center for Criminology and Socio-legal Studies at the University of Iowa. Crime and police expenditure data were obtained through the Inter-University Consortium for Political and Social Research (study \# 9028). Neither the consortium nor the original collectors of the data bear any responsibility for the analysis or interpretations presented here. I am very grateful to Karen Heimer, Kevin Leicht, Celesta Albonetti, Robert Baller, Peverill Squire, the editor of Criminology, and anonymous reviewers for helpful comments on earlier drafts of this paper.
\end{abstract}

This is the author's manuscript of the article published in final edited form as: Stucky, T. D. (2003). LOCAL POLITICS AND VIOLENT CRIME IN US CITIES*. Criminology, 41(4), 1101-1136. http://dx.doi.org/10.1111/j.1745-9125.2003.tb01015.x 


\section{Biographical Sketch}

Thomas D. Stucky is an Assistant Professor of Public and Environmental Affairs at IndianaPurdue University at Fort Wayne. His research interests are at the intersection of politics and crime and criminal justice, specifically the relationship between politics and crime/ policing, and statelevel trends in imprisonment and correctional spending. Please address all correspondence to Thomas D. Stucky, Public and Environmental Affairs, Indiana- Purdue University, 2101 E. Coliseum Blvd., Fort Wayne, IN 46805, stuckyt@ipfw.edu. 


\section{LOCAL POLITICS AND VIOLENT CRIME IN U.S. CITIES}

Recent research has begun to examine the effects of politics on crime. However, few studies have considered how local political variation is likely to affect crime. Using insights from urban politics research, this paper develops and tests hypotheses regarding direct and conditional effects of local politics on violent crime in 958 cities in 1991. Results from negative binomial regression analyses show that violent crime rates vary by local political structures and the race of the mayor. In addition, the effects of structural factors such as poverty, unemployment, and female- headed households on violent crime depend on local form of government and the number of unreformed local governmental structures. Implications for systemic social disorganization and institutional anomie theories are discussed. 
For most of the $20^{\text {th }}$ century, criminological studies paid little attention to politics. For instance, Bursik (1988) notes that classical social disorganization theory focuses nearly exclusively on internal community dynamics. Shaw and McKay (1972) assumed that the ecological factors affecting community development and social mobility patterns were natural processes (Bursik and Grasmick, 1993). Therefore, the context surrounding a community, such as the political environment, had little to do with community organization. Bursik $(1988,1989)$ argues that this is a significant shortcoming, because local governmental decisions can greatly affect community development patterns and ultimately crime. Similarly, Bursik and Grasmick (1993:53-55) suggest that governmental decisions regarding zoning and land-use are likely to have important consequences for residential stability and property values. Likewise, classical anomie theory focuses little attention on politics. However a recent reformulation of anomie theory_-institutional anomie theory — suggests that the impact of the economy on crime depends on the relative strengths of economic and non-economic institutions such as the polity (Messner and Rosenfeld, 1997a, 1997b). Cross-national (Savolainen, 2000) and state- level research (Chamlin and Cochran, 1995) testing institutional anomie theory suggests that politics can have direct and conditional effects on crime. In addition, other recent research suggests that aspects of local politics such as the race of the mayor can have direct effects on interracial homicide (Jacobs and Wood, 1999), police killings of minorities (Jacobs and O’Brien, 1998) and violence against police (Jacobs and Carmichael, 2002).

Because recent criminological research has begun to suggest that politics and crime are related, I argue that a fuller consideration of the implications of variation in local politics is in order. To date few criminological studies have considered the patterned ways that local political variation could affect crime or included direct measures of local politics. A voluminous body of urban politics research (summarized below) suggests that variation in local politics can have consequences for a number of social and political outcomes such as city council representation, voter turnout, and the responsiveness 
of city government to local concerns, which I argue are likely to affect crime rates. In the next section, I briefly discuss some of the ways politics has been discussed in recent systemic social disorganization and institutional anomie research, highlighting the need for more direct examination of how local political dynamics affect crime directly and conditionally. In addition, I discuss a few recent city-level studies that have included direct measures of local politics. Next, I discuss the impact of city politics on political and social outcomes. Then, I use insights from this research to generate some testable hypotheses on the relationship between local politics and crime.

\section{POLITICS IN PREVIOUS CRIMINOLOGICAL RESEARCH}

As noted above, classic social disorganization theory did not consider the relationship between the neighborhood and the larger community context. Recent research in systemic social disorganization theory has begun to address this lacuna. In particular, recent social disorganization research has focused on the role of public control in crime (Bursik and Grasmick 1993; McNulty and Holloway, 2000; Velez, 2001). Public control refers to the ability of neighborhoods to secure external resources through ties with the local government and police (Bursik and Grasmick, 1993: 17-18). Thus, systemic social disorganization theory predicts that neighborhood crime rates will depend, in part, on the ability of neighborhoods to extract resources from the city government. Consistent with this, Peterson et al. (2000) find that certain types of local institutions promote or inhibit violent crime rates in Columbus, Ohio neighborhoods. Not surprisingly, they find that bars have a criminogenic effect. However, they find that local recreation centers have a strong inhibiting effect on violent crime- but only in extremely

disadvantaged areas. Peterson et al. (2000) argue that certain local institutions mediate the link between disadvantage and violent crime. Libraries and recreation centers provide greater opportunity for interaction among community residents and structure their time- -thereby enhancing social control and reducing violent crime. Bars, on the other hand, are expected to increase the opportunity for crime and 
victimization. To the extent that communities can increase their local institutional base and fight the encroachment of disorganizing institutions such as bars, public control will be enhanced and violent crime reduced. Similarly, McNulty and Holloway (2000) find that the proximity to local public housing projects explains much of the race-violent crime relationship in 1990 census block groups in Atlanta. They argue that public housing projects anchor disadvantage and foster crime prone areas within the city. Bursik (1989) finds that the placement of public housing projects in Chicago in the 1970s occurred in the least stable neighborhoods, which he argues were least able to organize politically to block construction. Thus, public housing is related to crime and the placement of public housing depends on local political decisions. Finally, Velez (2001) —in a 60- neighborhood study across three cities_-finds that public control reduces the risk of personal victimization and this effect is strongest in very disadvantaged neighborhoods. Even small increases in public control lead to reductions in personal victimization risk in very disadvantaged areas, which traditionally have little public control. Because researchers have only recently begun to address mechanisms of public control, research has not yet systematically addressed the possibility that variation in local politics could affect public control. However, if public control is about the relationship between neighborhoods and the city government, then examining the internal determinants of neighborhood organization only addresses half the relationship. The external political environment is also likely to affect the ability of neighborhoods to develop the ties with local government necessary to increase public control and reduce crime. Thus, it makes sense to consider the structures and processes that are likely to affect city political responses to community attempts to secure resources.

Similarly, institutional anomie has begun to address the relationship of politics and crime. Institutional anomie theory suggests that the high crime rate in the United States is due to the overwhelming strength of economic institutions over non-economic institutions such as the schools, churches and the polity (Messner and Rosenfeld, 1997a). In a cross-national study of homicide rates, 
Messner and Rosenfeld (1997b) find a relationship between political restraint of the market and homicide. Homicide rates were lower in countries where the government protected citizens from the "vicissitudes of the market" through welfare programs. Similarly, Savolainen (2000) finds that the effect of inequality on homicide depends on the strength of the welfare state across countries. Specifically, the impact of inequality on homicide decreased as the strength of a country's welfare state increased. Similarly, Chamlin and Cochran (1995), in a state- level test of institutional anomie, found that the effect of poverty on property crime decreased as voter turnout increased. Thus, these studies suggest that crime depends on the relative strengths of political and economic institutions. These studies point to the critical role of governmental structure in determining crime at the national level. However, to date institutional anomie research has not considered variation in local politics. If variation in local politics affects the ways that governments protect citizens from market forces, then one must consider local as well as national politics. The urban politics research discussed below suggests that patterned variation in local politics across cities can have political and social consequences that I argue affect crime and the relationship between deprivation and crime.

In short, both institutional anomie and systemic social disorganization theory suggest the importance of examining the relationship between politics and crime but have not adequately considered how variation in local politics could affect crime. To date, only a few studies have examined how variation in local politics affects crime. This is perhaps because of the unit of analysis in previous research examining politics. Although national- level (e.g. Messner and Rosenfeld, 1997b; Savolainen, 2000), state- level (Chamlin and Cochran, 1995), and neighborhood- level (McNulty and Holloway, 2000; Velez, 2001) analyses yield important insights, they are not well suited for capturing the effects of variation in city-level politics.

Recently a few studies of crime have included direct measures of variation in local politics. For example Shihadeh and Flynn (1996), suggest that the political strength of groups within the city will 
have important consequences for crime. In a study of segregation and black crime rates in 150 large cities in 1990, they suggest that, “... [b]lack isolation from whites may also lead to political ... disenfranchisement of black neighborhoods (Shihadeh and Flynn, 1996: 1332).” Black social isolation may inhibit the ability of communities to procure services from the city government. This isolation inhibits the ability of the community to organize against crime. The authors suggest that one resource communities can have within the city is representation on city councils. Thus, cities with greater black political empowerment should have lower crime because they are able to garner important resources to limit the effects of isolation and thereby reduce crime. Similarly, Rosenfeld et al. (2001) in a study of social capital and homicide, include the proportion of the voting age population that voted as a measure of civic engagement. They argue that, “... high levels of civic engagement should strengthen social organization, and promote informal social control, thereby yielding lower levels of crime and violence (Rosenfeld et al., 2001: 286).” Thus, areas with high civic engagement should be better able to secure external resources such as policing necessary to control crime. They note that social disorganization, strain, and anomie theories suggest the relevance of social capital for reducing crime. One component of social capital—civic engagement—is related to politics. However, these authors do not account for the possibility that aspects of the structure of political systems could affect levels of civic engagement. Evidence from political science research suggests that it can. For instance, research suggests that nonpartisan voting systems depress voter turnout (Alford and Lee, 1968; Karnig and Walter, 1977, 1983). Jacobs' and his colleagues have also included direct measures of local political variation in three recent studies of city- level violence. Jacobs and O’Brien (1998) find that police killings of citizens are lower in cities with African- American mayors. Jacobs and Carmichael (2002) find that citizen killings of police and non-lethal assaults against police are less likely in cities with African- American mayors. Finally, Jacobs and Wood (1999) find that interracial homicides are affected by the presence of an African-American mayor. They find that whites kill blacks more often in cities with African- American 
mayors, whereas blacks kill whites less often in cities with African- American mayors. Thus, aspects of local politics clearly have implications for crime.

The consideration of certain aspects of politics in recent research on systemic social disorganization and institutional anomie theories and other recent city-level research discussed above represent important first steps in understanding the relationship of politics and crime. However, more work can be done to explain how local politics affects crime. I argue the best way to do that is to examine research on the causes and consequences of variation in local politics. In the next section, I briefly review urban politics research on the consequences of progressive era reforms.

\section{CITY POLITICAL STRUCTURES, REPRESENTATION AND PUBLIC POLICY}

One dominant theme in studies of urban politics has been the impact of progressive era reforms on local politics. ${ }^{1}$ During the nineteenth century, local government was dominated by patronage politics, where city officials traded favors for votes (see Banfield and Wilson, 1963). In the early twentieth century, reformers sought to limit the influence of machine politics by introducing changes in local government (Bridges and Kronick, 1999; Knoke, 1982). This discussion is limited to the three most common reforms. The first was to change form of government from an elected mayor to an appointed city manager. ${ }^{2}$ The second reform was to change electoral systems from district- based city council elections to at-large elections where council members were elected to represent the city as a whole. Finally, reformers sought to reduce machine politics by making elections formally nonpartisan. Table 1 provides operational definitions of the local political structures discussed. Because the term 'reform' has strong normative connotations, it is important to bear in mind that no normative preference is suggested in the use of the term in this context. It is retained here only because it is the standard term used in political science literature on the topic. To reduce the normative baggage associated with calling cities with mayor- council forms of government, partisan electoral procedures 
and geographically- based city council elections 'unreformed', I will refer to these as traditional local governmental structures in the discussions that follow.

Table 1 about here

Although the overt goal of reform was to produce governments concerned with the good of the entire city, a strong underlying theme was the desire of middle class businessmen to limit the political influence of working class, poor, and immigrant groups (Bridges and Kronick, 1999; Hofstadter, 1955). In the South, reformism became virtually synonymous with exclusion of blacks from the political process. Indeed, the link between electoral systems and black city council representation was so strong that court cases challenged the constitutionality of at-large election procedures (see Bullock and MacManus, 1993 for an overview). In the next section, I discuss research that has examined the effects of variation in the three major elements of reformism—-form of government, partisanship of elections, and city council electoral procedures—on political and social outcomes.

\section{LOCAL POLITICAL STRUCTURES AND REPRESENTATION}

Urban politics research has extensively examined the effect of various electoral systems on black city council representation. Early research suggested that at-large elections produced lower black representation than district elections (see Welch, 1990 for an overview). In district systems black candidates need only appeal to a small group of voter, who are more likely to be of similar race due to patterns of residential segregation. Some evidence suggests that the effect of at-large elections on black city council representation has declined in recent years, particularly outside the South (Bullock and MacManus, 1993; Sass and Mehay, 1995; Welch, 1990). However, Sass and Pittman (2000) found that the trend toward increasing black representation through the early 1990s stagnated later in the 1990s.

Extant research also suggests that partisanship of elections can affect the race and socioeconomic status of city council members (Bledsoe and Welch, 1985; Welch and Bledsoe, 1986, 1988). 
Partisan systems moderately favor the representation of poor and minority groups on city councils (Welch and Bledsoe, 1988) because political parties provide an important organizational resource that the poor and minorities can use to mobilize voters. In addition, because voters do not have party cues to follow in voting, name recognition becomes much more important in non- partisan elections. Therefore, non- partisan elections favor candidates with greater resources to advertise. Finally, nonpartisan local elections depress voter turnout (Alford and Lee, 1968; Karnig and Walter, 1977, 1983). All these factors moderately favor the election of white, middle and upper- class city council members in non-partisan elections.

Although research suggests that local political structures can affect who is elected to political office, it is reasonable to ask whether this has any policy implications. Many argue that there are good reasons to be skeptical about the potential influence of minority representation on local policy outcomes because of the need for coalition- building and the economic constraints that many cities face (e.g. Karnig and Welch, 1980: 150-152; Santoro, 1995: 795). Despite these constraints, some research suggests that increased black representation in city government could affect the kinds of policies implemented (e.g. Browning et al., 1984; Campbell and Feagin, 1975; Cole, 1976; Karnig and Welch, 1980). In particular, a large research literature has examined the relationship between local black representation and black municipal employment. Although not unequivocal, evidence suggests that increases in black city council and mayoral representation increase black municipal employment (Dye and Renick, 1981; Eisinger, 1982), particularly black police employment (Kerr and Mladenka, 1994; Salzstein, 1989).

\section{LOCAL POLITICAL STRUCTURE AND POLICY OUTCOMES}

Another line of research has examined whether structures of local government have any direct effect on local public spending (e.g. Liebert, 1974; Lineberry and Fowler, 1967; Lyons, 1978; Morgan 
and Pelissero, 1980; Morgan and Watson, 1995). For instance, Lineberry and Fowler (1967) found that city taxation and expenditure levels were more responsive to socio-economic and racial cleavages in traditional cities, which they argue was because of the necessity of satisfying the local electorate to maintain office. Similarly, Lyons (1978) argues that minority and poor driven calls for increases in city services are more likely to be heeded in mayor-council cities, whereas middle and upper class taxpaying homeowners will likely drive expenditures down in council- manager or commission cities. However, in a widely- cited study, Morgan and Pelissero (1980) found no differences in overall spending between reformed and traditional cities.

More recent studies have suggested that local political structures can affect municipal spending patterns but the relationship is conditional. For instance, Wong (1988) argues that local redistributive spending is the type most likely to be affected by organized interest groups within the city and reformed local governments reduce the ability of organized groups to affect the political process. Thus, reformed governments might not affect city expenditures for road construction but could reduce the responsiveness of the government to pressure for increases in public welfare spending. Similarly, Sharp (1991) finds that the link between local economic distress and economic development policy depends on the level of responsiveness of the city government, which in turn, depends (in part) on whether the government is reformed or not. Finally, Langbein, et al. (1996) argue that the effect of city council election procedures on spending will depend on whether the proposed expenditure benefits the whole city or only certain areas. They argue that cities with geographic city- council representation automatically represent the preferences of geographically concentrated groups better than at- large cities. Therefore, district cities will be more likely to favor spending where the benefit is geographically concentrated, whereas at- large cities will favor spending on programs benefiting the whole city. 
Finally, a few studies have examined the effect of reformism on the policy preferences of local officials. For example, Hansen (1975) found that the level of agreement between local officials and voters on local issue priorities depended on the competitiveness of local elections and citizen political participation, which in turn depended partly on partisanship of elections. Similarly, Shumaker and Getter (1983) found that city elites are most likely to respond favorably to advantaged groups in the city. However, party competition and a strong democratic party—which are less likely to be found in reformed cities_-reduced the responsiveness bias favoring advantaged groups.

In sum, evidence suggests that the three major components of progressive era reform-form of government, partisanship, and city council electoral rules—can have political and social implications. Urban politics research suggests that traditional local governmental structures somewhat enhance the election of the poor and blacks to city councils, which, in turn, can affect public policies. In addition, these structures of local government can directly affect spending patterns, economic development policies, the distribution of services within a city, and the responsiveness of local governments to the poor and minorities. Although criminological research has only recently begun to address the impact of various local political structures on crime, prior research has suggested a number of ways that local politics may have consequences for crime. In the next section I develop some testable hypotheses on the relationship between local politics and crime.

\section{LOCAL POLITICS AND CRIME}

\section{FORM OF GOVERNMENT}

City form of government is one source of local institutional political variation that has been posited to have criminal justice implications. Wilson and Boland (1978) find that police in councilmanager cities are more aggressive than in mayor-council cities, as indicated by the number of traffic citations written. They argue that the police departments in commission and city manager governments 
are more insulated from politics than in cities with elected mayors. Because elected mayors must satisfy the local electorate to maintain office, citizens are likely to have more leverage in trying to impact the policies of the police than in cities with managers appointed by the city council or commission governments which have no individual head of government to hold accountable. Thus, to the extent that city governmental form inhibits responsiveness of the police to citizen pressure, one would expect less positive relationships with the police. Jacobs and Wood (1999) and Jacobs and Carmichael (2002) suggest that interracial violence is higher in cities where black political efficacy is lower. If form of government affects the responsiveness of the police to minority groups, then one would expect decreased feelings of political efficacy and increased crime in city manager and commission cities.

In addition, because mayors must be re-elected, they must be concerned with the potential swing vote that organized groups represent. City managers and commissioners are likely to feel less pressure to respond to 'squeaky wheels' within parts of the city, since they are concerned with the city as a whole. Consistent with this, Lyons (1978) argues that minority and poor driven calls for increases in city services are more likely to be heeded in mayor-council cities. Therefore, on average one would expect that mayors would be more attentive to pressure from citizen groups to provide the services that poor and minority areas need, which Velez (2001) suggests leads to increased public control and lower crime. As a consequence, ceteris paribus, crime rates should be lower in mayor/council cities. Therefore, my first hypothesis is: Cities with mayor/council structures will have lower crime rates than those with council/manager or commission governments.

\section{CITY COUNCIL ELECTORAL SYSTEMS}

Another source of local political variation likely to affect the ties between citizens and local officials is structure of the local electoral system. As noted above, the weight of the evidence suggests 
that physical representation of poor and minority groups is greatest in cities with geographicallyoriented electoral systems (Sass and Pittman, 2000; Welch, 1990; Welch and Bledsoe, 1988; Zax, 1990). Although the link between increased physical representation of minorities on city councils and minority policy representation is not unambiguous, there is clear evidence that district council members consider their own district their highest priority, whereas at-large council members see the whole city as their constituency (Welch and Bledsoe 1988). No research that I am aware of compares crime across different city council electoral schemes. However, Rose and Clear (1998) suggest that the political organization of a community may be a critical factor in community organization against crime and local political participation is more likely to the extent that community residents believe that participation will produce results. Bledsoe (1986) found that district- based elections were associated with higher political efficacy for blacks. In other words, blacks are more likely to feel they have a say in local government in cities with district- based elections than at- large elections. Recall that Jacobs and Wood (1999) suggest that black political efficacy reduces violence against whites. Therefore, to the extent that district systems enhance the responsiveness of city council members to district- based concerns and increase the political efficacy of minority groups, one would expect crime to be lower in district than atlarge cities.

Another reason for this may be the way that city resources are allocated. If, as Wong (1988) suggests, organized interest groups affect redistributive spending within the city, then city political structures that maximize local interest group organization should produce the most redistributive spending. Because district cities represent the preferences of geographically concentrated groups better than at- large cities (Langbein et al., 1996), one might expect more redistributive spending in district cities than at-large cities, ceteris paribus. Recent research suggests that redistributive spending is directly related to crime. For instance, DeFronzo (1997) found that AFDC payments per recipient were 
directly negatively related with homicide. Thus, my second hypothesis is: Cities with district-based electoral systems will have lower crime rates than cities with at-large elections elections.

\section{PARTISANSHIP OF ELECTIONS}

As discussed above, extant research suggests that partisan systems favor somewhat greater physical representation of poor and minority city council candidates (Welch and Bledsoe, 1988) and increase voter turnout (Alford and Lee, 1968; Karnig and Walter, 1977, 1983). Research also suggests that partisanship enhances the responsiveness of local officials to citizen concerns (Hansen, 1975; Shumaker and Getter, 1983). Thus, one would expect that partisan elections should enhance the ability of citizen groups to cement ties to local public officials and secure public resources, which previous research suggests will be tied to reductions in crime (e.g. Velez 2001). If partisan elections enhance the ties of the local community with elected officials and increase the ability of communities to obtain the resources needed for public control, one would expect partisan cities to have lower crime rates, ceteris paribus. Thus, my third hypothesis is: Cities with partisan elections will have lower crime rates.

Throughout the preceding discussion of the effects of local governmental structure, I argued that certain political structures enhance the responsiveness of the local government. It stands to reason that if these traditional local institutional structures can enhance governmental responsiveness individually and reduce crime, they could also have a cumulative effect. It seems plausible that crime will be reduced as the number of these unreformed or traditional city governmental structures increases. Thus, my fourth hypothesis is: As the number of traditional local political structures increases crime rates will decrease. ${ }^{3}$ 


\section{INTERACTION OF LOCAL POLITICS, SOCIAL STRUCTURE AND CRIME}

Extant research suggests considerable empirical support for the relationship between social structural factors such as poverty and family disruption, and crime (e.g. Land et al., 1990; Miethe et al., 1991; Parker and McCall, 1999; Sampson, 1985, 1987). There are a number of plausible explanations for this link. For instance, systemic social disorganization theory suggests that social structural factors such as poverty and family disruption lead to a breakdown in community social control, which leads to crime (Bursik, 1988, 2000; Bursik and Grasmick, 1993). However, Rose and Clear (1998) argue that not all poor communities are disorganized. They suggest that the political organization of a community may be a critical factor in community organization against crime. They point to the existence of welldeveloped internal political institutions as key factors affecting the ability of the community to address problems that arise. This suggests that political organization could provide a buffer against the criminogenic effects of structural factors such as poverty and family disruption.

The urban politics research discussed above suggests that there may be structural reasons why some poor and minority communities may be more able to affect the political process than others. For instance, Lyons (1978) argues that mayor-council governments are more responsive to organized poor and minority group pressure because of the swing vote these groups represent. This variation in responsiveness to poor and minority groups is likely to have important consequences for the structural factors previously associated with social disorganization and institutional anomie, such as poverty and family disruption. Thus, in mayor- council governments, citizen pressure on local officials may produce needed resources in the community to reduce the effects of poverty or limit family disruption. Recall that Velez (2001) found that increases in public control reduces victimization most in the most disadvantaged communities. If Lyons (1978) is correct then poor communities in mayor-council cities will be better able to secure needed resources for public control and reduce crime. Therefore, local form of government is likely to affect the relationship between deprivation and crime rates. Thus, my 
fifth hypothesis is: The effect of deprivation on crime rates will be lower in cities with Mayor/council forms of government.

Institutional anomie theory suggests that the crime producing effects of economic conditions depends on the strength of non- economic institutions. Research at both the national and state level has found that the effect of the economy on crime depends on political factors. Recall that Savolainen (2000) finds that the effect of inequality on homicide depends on the strength of the welfare state. Similarly, at the state- level, Chamlin and Cochran (1995) found that the effect of poverty on crime depended on voter turnout. Thus, previous institutional anomie research at the national and state level suggests that the effect of the economy on crime is conditioned by politics. However, research to date has not examined the interaction of social structure, local politics and crime.

As noted above, research suggests that cities with partisan elections, elected mayors, and district- based city councils will be more responsive to the needs of poor and minority groups (e.g. Hansen, 1975; Shumaker and Getter, 1983). It also seems plausible that the increased responsiveness in these traditional political structures could affect the relationship between structural deprivation and crime. For instance, recall Wong's (1988) assertion that redistributive spending will be more likely in district cities and DeFronzo’s (1997) finding that welfare payments per capita were directly related to homicide. If district cities are more generous with welfare payments then one can expect them to have lower violent crime than at-large cities. As a consequence, these cities will be more likely to institute programs to reduce the impact of poverty and unemployment, and as a consequence have lower crime rates. Likewise, previous research suggests that voter turnout is higher in partisan cities. Because, previous research has shown a relationship between voter turnout, poverty, and crime at the state- level, it seems worthwhile to examine whether the same relationship inheres at the local level. As noted above, institutional anomie research suggests a national- level link interaction between the economy, politics and crime. The research discussed here suggests that this may translate to the city level as well. 
Thus, my sixth hypothesis is: As the number of traditional local political structures increases, the effect of deprivation on crime will decrease.

\section{RACE OF LOCAL OFFICIALS}

To this point, the discussion has focused on characteristics of local political structure. The urban politics research, discussed above, also examined the effect of actors within the system. As noted above, although some research questions their potential influence (Karnig and Welch, 1980: 150152; Santoro, 1995: 795), some evidence suggests that minority local officials can affect local policies (e.g. Browning et al., 1984; Campbell and Feagin, 1975; Karnig and Welch, 1980). For instance, Browning et al. (1984) found that black city council representation was associated with civilian police review boards and other research suggests that black representation increases black police employment (Dye and Renick, 1981; Kerr and Mladenka, 1994; Salzstein, 1989). A few previous studies have suggested direct connections between minority representation and crime.

For instance, Shihadeh and Flynn (1996) suggest that the political strength of groups within the city will have important consequences for crime. They argue that black social isolation may also lead to political exclusion of black neighborhoods. In particular, they examine the level of black representation on city councils. To quantify black political empowerment within cities, Shihadeh and Flynn (1996) measure of black city council representation equity, which is the proportion of city council members that are black, divided by the proportion of city's voting age population that is black. Values less than one indicate that the black community is politically underrepresented and values equal to or greater than one suggest that the black community is politically empowered. Thus, cities with greater black political empowerment should have lower crime because they are able to garner important resources to limit the effects of isolation and thereby reduce crime. Although Shihadeh and Flynn (1996) did not find consistent effects of black political empowerment on black violence, it is worth considering whether other measures of local minority political strength matter for crime. It seems 
plausible that absolute black political empowerment could be more important than relative equity of council representation. For example, according to their equity measure, a city with a 5\% black population would be over-represented on a city council if 1 council member out of 10 were black. However, an absolute measure would predict the power of that single black council member to affect policy to be small. Therefore, it is worthwhile to examine different measures of black political empowerment on city council to determine if there are differences in crime rates. Thus, my seventh hypothesis is: Crime rates will be lower in cities with higher black city council representation.

Studies have also suggested that the race of the mayor can have direct criminal justice consequences as well. For instance, Salzstein (1989) finds that cities with black mayors have higher black police employment and are more likely to institute civilian review boards for police. One would expect that increased minority involvement in the police force and the institution of civilian review boards would enhance the quality of the relationship between the minority community and the police. Research by Jacobs and his colleagues suggests that the race of the mayor has direct implications for crime. They find that minority killings by police (Jacobs and O’Brien, 1998) and both lethal and nonlethal violence against police (Jacobs and Carmichael, 2002) are less likely in cities with AfricanAmerican mayors. Jacobs and Carmichael (2002) suggest that the link between the race of the mayor and crime may be due to the perception of injustice by minorities. They suggest that some crimes result from feelings of injustice and that this sense of injustice leads to lashing out against the perceived majority - the most visible agents of which are the police. The presence of a black mayor reduces these feelings of injustice and increases feelings of political efficacy (Bobo and Gilliam, 1990). Therefore, it is reasonable to expect that the presence of a black mayor may reduce black feelings of injustice and lead to more positive relationships between the minority community and the police, ultimately reducing crime. Thus, my eighth hypothesis is: Crime rates will be lower in cities with black mayors. 


\section{SUMMARY}

In sum, recent city- level studies have suggested that politics may play a role in crime. Urban politics research suggests that local politics can affect the responsiveness of the city government to organized groups within the city and policy outcomes. I argue that this variation in governmental responsiveness will affect crime rates. The research discussed above suggests that the structures and processes of local government can affect policies of the police and crime. Although it is important not to overstate the policy differences that result from differences in local politics, Velez (2001) suggests that even small differences in public resources can reduce victimization in very poor neighborhoods. In the next section, I discuss the data and methods used to test the hypotheses discussed above.

\section{DATA AND METHODS}

To assess the hypotheses discussed above, I selected the 1071 cities with 25,000 or more residents in 1990 listed in the County and City Databook, 1994 (U.S. Department of Commerce, 2000). Missing data reduced the sample size by about $10 \%$ to 958 . However, other than having a slightly larger mean population (104,000 v. 88,000), the missing cases do not appear to affect the demographic characteristics of the sample. The dependent variable is measured in 1991, and predictor variables are measured in 1990 (unless otherwise noted) so that the temporal ordering of measured variables would correspond to the implied causal ordering of arguments. The details of variable construction are discussed below.

\section{MEASURES}

The current study measures crime using the crimes known to the police from the Uniform Crime Reports (UCR) (U.S. Dept. of Justice, 2000) because it is the only crime measure available for a sufficient number of cities to provide variation in local political structures and is considered a 
reasonably accurate reflection of serious crime (Gove et al., 1985; LaFree, 1998). Following other recent studies (McNulty and Holloway, 2000; Peterson et al., 2000; Velez, 2001), I examine violent crime, which includes murder, rape, robbery, and aggravated assault, in 1991.

All city institutional political variables were obtained from the 1991 Form of Government (FOG) survey conducted by the International County/ City Management Association (Urban Data Service, 1992) (see Appendix A for questionnaire items). ${ }^{4}$ For the analyses reported below, I created a categorical variable indicating city form of government called mayor-council, coded 1 for cities with mayor/ council governments and 0 for council- manager and commission cities. ${ }^{5}$ City council electoral procedures were captured in the at-large variable. At-large, is coded 1 if all city council members are nominated and elected to serve the whole city, and 0 otherwise. Thus, the excluded reference category includes cities where at least some members of the council are elected to represent geographic areas within the city. Partisan is coded 1 if the political party affiliation of candidates appears on the ballot in local general elections, and 0 otherwise. Finally, to capture the cumulative effects of these local political structures, I create a variable, traditional government structure index, where 1 is added to the index for each unreformed local political structure (mayor-council, district or mixed, and partisan). Therefore, this variable ranges from 0-3. Unfortunately, information on local political structures was missing for a number of cities in the sample. To reduce the number of missing cases and the possibility that reporting errors on the FOG survey impact the analyses, the 1981, 1986 and 1996 FOG surveys (Urban Data Service, 1982, 1987, 1997) were examined. Where there was consistency in a political structure before and after 1991, that value was substituted for the missing 1991 value. Where any ambiguity remained, calls were placed to each mayor or city clerk’s office to verify the political structures in 1991, whether missing or seemingly the result of reporting error on the FOG survey. In addition, the race of city officials was available in the FOG survey for 722 cities in the sample. Therefore, I created a categorical variable named black mayor, coded 1 if the city’s mayor was 
African- American in 1991, and 0 otherwise. I also created two measures of black city council representation. Black city council proportion is the number of black city council members divided by the total number of city council members.

Previous research has also identified a number of social structural factors that are related to crime such as poverty, family disruption, (Land et al., 1990). However, in preliminary OLS analyses using separate social structural factors, variance inflation factors (VIF) exceeded 10, indicating severe multicollinearity (Neter et al., 1996). Therefore, following previous research (e.g. Land et al., 1990; Parker and McCall, 1999), I created an index, which I call deprivation. Principal components analyses produced a factor with the following indicators: percent poor in 1989, percent unemployed in 1991, percent of owner- occupied homes in 1990, and percent of female- headed households in 1990. Factor loadings for all variables were quite high -.72 to .91 . I generated factor scores for each city based on the 4 variables listed above. Following social disorganization theory, the percentage of the city's population that was foreign born in 1990 is included separately as a measure of ethnic heterogeneity. In addition, the percentage of the city's population that is black and the percentage that is Hispanic are also included as separate independent variables (both natural logged to reduce skewness). ${ }^{6}$ Including the deprivation index in analogous OLS regression equations substantially reduced maximum VIFs (less than 4.0 in all reported results), suggesting that multicollinearity did not affect reported results.

Population density and percent population change have also been linked to crime in prior research (see Land et al., 1990). Therefore, percent population change (from 1980 - 1992) and population density (rate of 1992 population per square mile are included in reported analyses. Also, prior research on the distribution of crime across the life course suggests that crime commission rises through the teen years, then, declines from the early twenties on (see Gottfredson and Hirschi, 1990 for a review). Failure to control for the size of the youthful population could mean that differences in crime across cities could be due to variation in the size of the most crime- prone population. Therefore, the 
natural log of the percentage of population age 18 to 24 in 1990 is included. Another variable included in many previous city- level analyses of crime is regional location (e.g. Parker and McCall, 1999; Shihadeh and Flynn, 1996). South is a categorical variable coded 1 for cities in southern states (AL, AR, FL, GA, KY, LA, MD, MS, NC, SC, VA, and TX) and 0 otherwise. Few previous city-level studies of crime have included any measure of local finances. However, one major tool city governments have to deal with local problems is through expenditures. It seems plausible that cities that spend more on their citizens will have lower crime rates. For instance, DeFronzo (1997) found that AFDC payments per recipient were significantly negatively related to homicide in 141 cities. Unfortunately welfare expenditures were not available for a sufficient number of cities in the sample. Therefore, the impact of overall city expenditures per resident will be assessed. This variable is measured as city expenditures (in dollars) per resident in the 1990- 1991 fiscal year. ${ }^{7}$ Because reported crime could be a function of policing levels (see Levitt 1998), I also include a measure of police spending, which is the city expenditures for policing per resident (in hundreds of dollars) in the 19901991 fiscal year. Finally, to address potential unobserved heterogeneity, the natural log of violent crimes in 1990 is included in all reported models. ${ }^{8}$ This provides a stringent test for explanatory variables in the model because prior violent crime explains a large proportion of the variance in the dependent variable (Morenoff, et al. 2001). See Appendix B for means and standard deviations and Appendix C for bivariate correlations of variables used in the analyses.

\section{STATISTICAL MODELS}

Preliminary analyses showed that the dependent variable is highly skewed. This is probably due to the large range in the size of cities included in the sample. The smallest cities in the sample had only 25,000 residents whereas the largest cities had more than 1 million residents. Although previous research has often dealt with this issue through log transformation of the dependent variable, Osgood 
(2000) shows the superiority of Poisson- based models for aggregate crime rate data. Transforming Poisson regression of counts into the rate data of interest in the current study is accomplished by including the natural log of the population in 1991 in the linear model and fixing the coefficient to 1, following standard practice in discussions of Poisson- based analyses (see Gardner et al., 1995; Osgood, 2000; Osgood and Chambers, 2000). The Poisson model also assumes that the linear model adequately explains the variation in violent crime across cities. In essence, the Poisson model assumes that there is no residual dispersion left to explain, once the explanatory variables are included in the model. The negative binomial models reported in Table 2 avoid this unrealistic assumption by including an estimated dispersion parameter to account for residual variance. ${ }^{9}$

\section{RESULTS}

Table 2 presents the results of four negative binomial regression equations predicting the rate of violent index crimes per 100,000 residents in 1991. Equation 1 includes several variables suggested by prior research to be related to crime. To assess overall model fit, one can use a likelihood ratio test, which is computed as twice the difference between the log- likelihoods of the models being compared. This value is then compared to the $\mathrm{X}^{2}$ distribution, with degrees of freedom equal to the difference in the number of parameters between the two models being compared (Osgood and Chambers, 2000). In this case, one is comparing equation 1 to a model with only a dispersion parameter and an intercept. The $X^{2}$ value $=1491.4$ which is highly significant $(\mathrm{p}<.0001)$, suggesting that the model fits the data very well.

Turning to the effects of individual variables, as expected, violent crime in the previous year is strongly positively associated with violent crime in the current year in all equations in Table 2 (p < .0001). Also, (as shown in the deprivation index) structural factors such as: female- headed households, poverty, unemployment are highly significantly positively associated with crime rates $(\mathrm{p}<.0001)$. In 
the negative binomial model, the beta coefficient refers to the proportional change in the dependent variable when the independent variable changes by one unit (Cameron and Trivedi, 1998). Therefore, one would expect violent crime to be $26 \%$ higher for each unit increase in the deprivation indexwhich is approximately a standard deviation because this is an index. Both the natural log of the percent of the population that is black and the natural log of the percent of the population that is Hispanic are highly significantly related to the natural log of violent crime rates in $1991(\mathrm{p}<.0001)$, net of the other factors in the model. Thus, violent crime increases as the percentage of AfricanAmericans and Hispanics in the population increases. However, percent foreign born, percent population change, and population density are not significantly related to violent crime rates in 1991, net of prior crime and the other factors in the model. Percent of the population age 18-24 is strongly negatively related to violent crime in all reported results, net of the other factors in the model. It is possible that the individual link between age and crime does not translate to higher levels of aggregation. In other words, it could be that younger cities have aggregate crime- reducing effects that run counter to the individual relationship between age and crime. Cities located in southern states have significantly higher violent crime rates than cities in non-southern states, even controlling for the other factors in equation $1(\mathrm{p}<.05)$. Contrary to expectations, police spending is actually significantly positively related to crime $(\mathrm{p}<.0001)$. This could be because the variables are measured contemporaneously, but it is unlikely that current violent crime rates affect current police spending because local budgets take time to develop. As predicted, overall city expenditures are significantly negatively related to violent crime rates $(\mathrm{p}<.0001)$ across all models reported in Table 2 . Thus, controlling for the other factors in the model, cities with higher expenditures per resident have lower violent crime rates. It appears that, when it comes to violent crime, cities get what they pay for. 
Equation 2 adds the local political structural variables discussed above. Contrary to hypothesis 1 , mayor- council cities do not have significantly lower violent crime rates than councilmanager and commission cities $(\mathrm{p}=.1534)$, controlling for the other factors in the model (although the coefficient is in the expected direction). Consistent with hypothesis 2, city council electoral procedures appear to be significantly related to crime. Cities with purely at- large council elections have significantly higher violent crime rates $(\mathrm{p}<.01)$ than cities where some or all of the council members are elected to represent geographic districts within the city. Thus, net of prior crime and the other factors in the model, one would expect violent crime to be $8.3 \%\left(\mathrm{e}^{.080}\right)$ higher in purely at-large cities than those with some form of geographically based city council representation. Contrary to hypothesis 3, partisan cities did not have significantly lower violent crime rates than nonpartisan cities, controlling for the other factors in the model, although the variable did approach significance $(p=.105)$ and was in the predicted direction.

Consistent with hypothesis 5, the effect of social factors such as poverty, unemployment and family disruption on violent crime depends on the local form of government. The significant negative value $(\mathrm{p}<.01)$ for the interaction term between the deprivation index and mayor- council means that the structural factors included in the index have less of an impact on violent crime in mayor- council cities, controlling for prior violent crime and the other factors in the model. To illustrate this, consider the differences in predicted violent crime rates by form of government. Because the mayor-council variable has a value of 0 in council- manager and commission cities, the interaction term drops out of the prediction equation for those cities. Thus, the effect of structural deprivation on violent crime rates in council- manager and commission cities is the main effect for the deprivation index. In mayorcouncil cities, the addition of the coefficient for the interaction term (-.096) reduces the effect of structural indicators of deprivation on violent crime rates by 31\% (.096 / .309) over council- manager and commission cities, controlling for the other factors in the model. ${ }^{10}$ It is also interesting to note that 
the effect of the southern region variable drops to non- significance once the political structural variables are included in the model. Thus, some of the regional differences in crime between southern and non-southern states found in previous studies could have been due to the failure to control for local politics.

Equation 3 substitutes the traditional government structures index to capture the cumulative effects of mayor-council forms of government, partisan elections, and district- based city council representation. The traditional government structures index is significantly negatively related to violent crime ( $\mathrm{p}<.0001)$, controlling for the other factors in the model. Thus, consistent with hypothesis 4 , as the number of traditional local political structures increases violent crime decreases. Equation 4 also includes the interaction between traditional government structures index and the deprivation index. Consistent with hypothesis 6 , the coefficient for this interaction term is negative and significant (p < .05). Substantively this means that the effect of poverty, unemployment, marital disruption, and homeownership on violent crime weakens as the number of representation enhancing local political structures increases.

\section{RACE OF LOCAL PUBLIC OFFICIALS AND CITY VIOLENT CRIME RATES}

In addition to the effect of local political structures on physical representation of blacks, the research discussed above suggests that the race of officials occupying local governmental positions may also affect local policies and crime. Consistent with Jacobs’ recent research (Jacobs and Carmichael, (2002; Jacobs and Wood, 1999; Jacobs and O’Brien, 1998) and Shihadeh and Flynn (1996), I hypothesized that black local officials would enhance the ties of poor, minority residents to the local government, which, in turn, should reduce violent crime. Equation 4 includes the black city council proportion variable and the categorical variable for whether the mayor is black, following hypotheses 7 and $8 .^{11}$ As noted above, race of mayor and city council member information was only available for 
722 cities in the sample. However, the results from equation 4 are substantively similar to equation 3, suggesting that the model is not sensitive to the sample. Contrary to hypothesis 7 , the proportion of the city council that is black is not significantly related to crime. Equation 4 also includes a dichotomous measure of the race of the mayor, coded 1 if the city's mayor was black, and 0 otherwise. Consistent with hypothesis 8 , having a black mayor is significantly related to violent crime. Thus, net of prior violent crime, local political structures and the other factors in the model, one would expect violent crime to be $20.6 \%\left(\mathrm{e}^{.187}\right)$ lower in cities with an African- American mayor. ${ }^{12}$

\section{CONCLUSION}

In sum, the current study considered the effect of variation in local political arrangements on violent crime rates across cities. This study found that local politics had direct and conditional effects on violent crime. Specifically, the study found that violent crime rates were lower in cities where at least some city council members are elected to serve geographic districts. Thus, there appears to be something about district- based city council representation that reduces violent crime. The urban politics research discussed above suggests that this may be because district- based political representation enhances the responsiveness of local governments, which may in turn, lead to policies that reduce violent crime. Likewise, violent crime went down as the number of unreformed or what I termed traditional local political structures increased. This offers more evidence for the notion that certain local political arrangements enhance or inhibit the accessibility of local officials in ways that help reduce crime. In addition, the effects of structural indicators of deprivation, such as poverty and family disruption, on violent crime were lower in cities with mayor- council forms of government and as the number of traditional local governmental structures increased. Thus, there appears to be something about certain local governmental structures that weaken the relationship between deprivation and crime. The study also found that, controlling for prior violent crime, local political structures and 
the other factors in the model, cities with African- American mayors had lower violent crime rates. This is consistent with previous research showing that the race of the mayor can affect crime (e.g. Jacobs and Carmichael, 2002; Jacobs and Wood, 1999).

These results have implications for systemic social disorganization and institutional anomie theories. Systemic social disorganization theory suggests that political organization may be a source of community social control that helps reduce crime. Likewise, institutional anomie theory suggests that the effect of the economy on crime depends on the strength of political institutions. However, neither perspective has considered the possibility that there may be patterned variation in local politics that could affect crime. The urban politics research discussed above and the results of the current study suggest that both institutional anomie and systemic social disorganization perspectives could profit from examination of how the direct and conditional effects of local politics on violent crime.

Recent research from the institutional anomie perspective has begun to consider the direct and conditional effects of politics on crime. For example, Savolainen (2000) found that cross-national variation in homicide rates depended in part on the strength of the welfare state. Likewise, Chamlin and Cochran (1995) found that the relationship between economic conditions and crime depended on the strength of non-economic institutions. The current study showed that local political variation affects violent crime and the relationship between economic conditions and crime. Therefore, future research on institutional anomie needs to further specify the dimensions of non-economic institutions and how these affect crime directly and the relationship between economic institutions and crime.

This study also has implications for research from the systemic social disorganization perspective. As noted above, recent research in social disorganization has focused on public control, which refers to the ability of neighborhoods to secure external resources through ties with the local government and police (Bursik and Grasmick, 1993). Thus, systemic social disorganization theory predicts that neighborhood crime rates will depend, in part, on the ability of neighborhoods to extract 
resources from the city government. However, these studies focus nearly exclusively on the internal aspects of public control. The results of the current study suggest that future research on public control needs to focus on the external aspects of this relationship and examine the role local governmental structure plays in constraining or enabling local community organization and the responsiveness to community demands for services.

Similarly, some have recently begun to argue that politics has an impact on parochial levels of control as well. Recent work by Sampson and Morenoff and their colleagues (Morenoff et al., 2001; Sampson et al., 1997; Sampson and Raudenbush, 1999) suggests that collective efficacy is one important source of local community control that mediates the effect of social structural disadvantage on crime. Similarly, Rosenfeld et al. (2001) include voter turnout as one indicator of civic engagement in their measure of social capital. However, no criminological studies have addressed the possibility that local political variation could systematically affect parochial control. The urban politics literature suggests some good reasons to believe that local politics is likely to have patterned effects on parochial control as well. For instance, as noted above, non-partisan elections depress voter turnout—one of Rosenfeld et al.'s, (2001) measures of civic engagement. Likewise, Bledsoe (1986) found that district elections were associated with higher political efficacy for blacks. In other words, blacks are more likely to feel they have a say in local government in cities with district- based elections than at large elections. Thus, how local politics affects parochial control should be addressed in the future as well. This study also has wider implications for criminology. It suggests the value of considering how local politics structures the relationships between citizens, the local government, and the police. For instance, given recent attention to community policing (e.g. Skogan and Hartnett, 1997), it seems reasonable to wonder whether local political structures affect the likelihood of implementation and success of community policing programs. Research suggests that the adoption of community policing programs often occurs as the result of community pressure (Zhao, 1996). If reformed local 
governments make elites less tuned to the priorities of the citizens, reformed governments could be less likely to implement community policing or develop and maintain the relationships with poor communities to make it successful. Finally, segregation is an important issue in both studies of race and crime (Peterson and Krivo, 1993; Shihadeh and Flynn, 1996) and black city council representation (Vedlitz and Johnson, 1982). Future studies will examine the joint impacts of race, residential segregation, and local politics on violent crime.

It is important to recognize the limitations of the current study. First, the urban politics studies discussed here do not predict dramatic differences across cities based on variation in local political structures. However, Velez (2001) argues that in high crime areas even small increases in external resources can reduce victimization rates. Thus, even if the differences between reformed and unreformed governments are not dramatic, they may be enough to have an impact on violent crime. Second, the current study employed relatively crude measures of politics due to limited data availability. Thus, these measures can only serve as proxies for responsiveness. Future studies will need to find measures that are better able to directly measure the responsiveness of local governments and the effect of this responsiveness on crime. For instance, data on variation in the policy outputs of various local governments such as community block grants or welfare spending would provide a better picture as to the mechanisms through which local politics affects crime. In addition, future studies will need to examine how party politics affects the outcomes discussed here. For instance, given the Republican focus on law and order in recent years (e.g. Jacobs and Helms, 1996), it is reasonable to wonder whether the party of local officials affects crime.

In sum, criminological studies have only recently begun to consider the impact of local political structural variation on violent crime. Historians of urban politics have suggested that one of the goals of reform was to reduce the political clout of the poor and minorities. The empirical studies discussed above suggest that there are some lingering differences in the way local governments respond to citizen 
pressure based on differences in local governmental structure. The results of the current study suggest that this affects city- level variation in violent crime. The importance of local political structures for violent crime in the current study also suggests the value of expanding on traditional explanations of crime by applying insights from research outside mainstream criminology. 


\section{NOTES}

1. For overviews of the history of progressive era reforms see Banfield and Wilson, 1963; Fox, 1977; Griffith, 1974; Hofstadter, 1955).

2. Council-manager cities have mayors but they are usually selected from among city council members rather than being directly elected and do note drive policy as they do in mayor-council cities.

3. It is important to keep in mind that these unreformed governmental structures are posited to lead to responsiveness rather than being direct indicators of governmental responsiveness.

4. This raises potential causal order issues. However, it is quite unlikely that the current crime rate will be an important factor in cities changing their form of government.

5. Only 11 cities in the sample had commission governments. It is also possible to have town meeting and representational town meeting forms of government but no cities in the sample had either form.

6. Alternative models that included percent black in the deprivation index produced similar results.

7. This again raises the issue of causal order. However, because city budgets take time to develop, current city expenditures are more likely to influence crime rates than the reverse.

8. For an example see Table 5 of Sampson and Raudenbush (1999).

9. The advantage of including this parameter in the model is that when there is no overdispersion in the model, the parameter estimate is 0 and the negative binomial model reduces to the Poisson model. 10. I also tested to see if region interacted with the political effects discussed here. No significant interactions between local politics and region were found.

11. Previous research in urban politics limited samples to cities with $5 \%$ or $10 \%$ black populations assuming that blacks must make up a sufficient proportion of the electorate to obtain the threshold of support necessary for election (e.g. Karnig, 1979; Karnig and Welch, 1982; Welch, 1990). This appears to be unduly restrictive because 26 cities with less than 5\% black populations and 61 cities with less than $10 \%$ black populations in the current sample had black city council members. 
12. An alternative model substituting Shihadeh and Flynn’s (1996) black city council population ratio produced similar results. In addition, although the correlation between percent black and the black city council proportion is quite high (.83), alternative models that reduced the potential for multi-collinearity by including percent black in the deprivation index yielded similar results. Finally, models that included black mayor, black city council proportion or ratio variables separately produced substantively similar results. 
Alford, Robert and Eugene Lee

\section{REFERENCES}

1968 Voting Turnout in American Cities. American Political Science Review 62:796-813.

Banfield, Edward and James Q. Wilson

1963 City Politics. New York: Vintage Books.

Bledsoe, Timothy

1986 A Research Note on the Impact of District/ At-Large Elections on Black Political Efficacy. Urban Affairs Quarterly 22:166-174.

Bledsoe, Timothy and Susan Welch.

1985 The Effect of Political Structures on the Socioeconomic Characteristics of Urban City Council Members. American Politics Quarterly 13:467-483.

Bobo, Lawrence, and Franklin D. Gilliam

1990 Race, Sociopolitical Participation, and Black Empowerment. American Political Science Review 84:377-393.

Bridges, Amy and Richard Kronick

1999 Writing the Rules to Win the Game: The Middle-Class Regimes of Municipal Reformers. Urban Affairs Review 34:691-706.

Browning, Rufus, Dale Rogers Marshall and David H. Tabb

1984 Protest is not Enough: The Struggle of Blacks and Hispanics for Equality in Urban Politics. Berkeley: University of California Press.

Bullock, Charles S. III and Susan A. MacManus

1993 Testing Assumptions of the Totality-of- the- Circumstances Test: An Analysis of the Impact of Structures on Black Descriptive Representation. American Politics Quarterly 21:290-306. 
Bursik, Robert. J.

1988 Social Disorganization and Theories of Crime and Delinquency: Problems and Prospects. Criminology 26:519-551.

1989 Political Decision-making and Ecological Models of Delinquency: Conflict and Consensus. In Steven F. Messner, Marvin D. Krohn, and Allen E. Liska (eds.), Theoretical Integration in the Study of Deviance and Crime. Albany: State University of New York Press.

2000 The Systemic Theory of Neighborhood Crime Rates. In Sally S. Simpson (ed.), Of Crime and Criminality. Thousand Oaks, CA: Pine Forge Press.

Bursik Jr., Robert J. and Harold G. Grasmick

1993 Neighborhoods and Crime: The Dimensions of Effective Community Control. New York: Lexington Books.

Cameron, A. Colin, and Pravin K. Trivedi

1998 Regression Analysis of Count Data. Cambridge University Press.

Campbell, David and Joe R. Feagin

1975 Black Politics in the South: A Descriptive Analysis. The Journal of Politics. 37:129-162.

Chamlin, Mitchell B., and John K. Cochran

1995 Assessing Messner and Rosenfeld’s Institutional Anomie Theory: A Partial Test. Criminology 33: 411-429

Cole, Leonard

1976 Blacks in Power. Princeton, N.J.: Princeton University Press.

DeFronzo, James

1997 Welfare and Homicide. Journal of Research in Crime and Delinquency. 34:395-406. 
Dye, Thomas R., and James Renick

1981 Political Power and City Jobs: Determinants of Minority Employment. Social Science Quarterly 62:475-486.

Eisinger, Peter K

1982 Black Employment in Municipal Jobs. American Political Science Review 76:380-392.

Fox, Kenneth

1977 Better City Government: Innovation in American Urban Politics 1850-1927. Philadelphia: Temple University Press.

Gardner, William, Edward P. Mulvey, and Esther C. Shaw

1995 Regression Analyses of Counts and Rates: Poisson, Overdispersed Poisson, and Negative Binomial Models. Psychological Bulletin 118:392-404.

Gottfredson, Michael R. and Travis Hirschi

1990 A General Theory of Crime. Stanford, CA: Stanford University Press.

Gove, Walter R., Michael Hughes, and Michael R. Geerken

1985 Are Uniform Crime Reports a Valid Indicator of the Index Crimes? An Affirmative Answer with Minor Qualifications. Criminology 23:451-510.

Griffith, Ernest S.

1974 The Progressive Years and their Aftermath, 1900- 1920. New York: Praeger.

Hansen, Susan Blackall

1975 Participation, Political Structure and Concurrence. The American Political Science Review 69:1181-1199.

Hofstadter, Richard

1955 The Age of Reform. New York: Random House 
Jacobs, David, and Jason T. Carmichael

2002 Subordination and Violence Against State Control Agents: Testing Political Explanations for Lethal Assaults Against the Police. Social Forces 80:1223-1251.

Jacobs, David, and Ronald E. Helms

1996 Toward a Political Model of Incarceration: A Time-Series Examination of Multiple Explanations of Prison Admission Rates. American Journal of Sociology 102:323-357.

Jacobs, David, and Robert M. O’Brien

1998 The Determinants of Deadly Force: A Structural Analysis of Police Violence. American Journal of Sociology 103:837-862.

Jacobs, David, and Katherine Wood

1999 Interracial Conflict and Interracial Homicide: Do Political and Economic Rivalries Explain White Killings of Blacks or Black Killings of Whites? American Journal of Sociology 105:157-190.

Karnig, Albert K

1979 Black Resources and City Council Representation. Journal of Politics 41:134-149

Karnig, Albert K., and Oliver Walter

1977 Municipal Elections: Registration, Incumbent Success and Voter Participation. In Municipal Yearbook, 1977 Washington, D.C: International City Management Association.

1983 Decline in Municipal Voter Turnout. American Politics Quarterly 11:491-506.

Karnig, Albert K. and Susan Welch

1980 Black Representation and Urban Policy. Chicago, Ill: University of Chicago Press.

1982 Electoral Structure and Black Representation on City Councils. Social Science Quarterly 63:99-114. 
Kerr, Brinck and Kenneth R.Mladenka

1994 Does Politics Matter? A Time-Series Analysis of Minority Employment Patterns. American Journal of Political Science 38:918-943.

Knoke, David

1982 The Spread of Municipal Reform: Temporal, Spatial, and Social Dynamics. American Journal of Sociology 87:1314-1339.

LaFree, Gary D.

1998 Losing Legitimacy: Street Crime and the Decline of Social Institutions in America. Boulder, CO: Westview Press.

Land, Kenneth C., Patricia L. McCall, and Lawrence E. Cohen.

1990 Structural Covariates of Homicide rates: Are there any Invariances Across Time and Social Space? American Journal of Sociology 95:922-963.

Langbein, Laura I., Philip Crewson and Charles Neil Brasher

1996 Rethinking Ward and At-Large Elections in Cities: Total Spending, the Number of Locations of Selected City Services and Policy Types. Public Choice 88:275-293.

Levitt, Steven D.

1998 The Relationship Between Crime Reporting and Police: Implications for the Use of Uniform Crime Reports. Journal of Quantitative Criminology 14:61-81.

Liebert, Roland J.

1974 Municipal Functions, Structure, and Expenditures: A Reanalysis of Recent Research. Social Science Quarterly 54:765-783.

Lineberry, Robert L. and Edmund P. Fowler

1967 Reformism and Public Policies in American Cities. The American Political Science Review 61:701-716. 
Lyons, William

1978 Reform and Response in American Cities: Structure and Policy Reconsidered. Social Science Quarterly 59:118-132.

McNulty, Thomas L. and Steven R. Holloway

2000 Race, Crime and Public Housing in Atlanta: Testing a Conditional Effect Hypothesis. Social Forces 79:707-729.

Messner, Steven F., and Richard Rosenfeld

1997a Crime and the American Dream, $2^{\text {nd }}$ ed. Belmont, CA: Wadsworth.

1997b Political Restraint of the Market and Levels of Criminal Homicide: A Cross- national Application of Institutional- Anomie Theory. Social Forces 75: 1393-1416.

Miethe, Terance D., Michael Hughes, and David McDowall

1991 Social Change and Crime Rates: An Evaluation of Alternative Theoretical Approaches. Social Forces 70:165-185.

Morenoff, Jeffrey D., Robert J. Sampson, and Steven W. Raudenbush

2001 Neighborhood Inequality, Collective Efficacy, and the Spatial Dynamics of Urban Violence. Criminology 39:517-559.

Morgan, David R. and John P. Pelissero

1980 Urban Policy: Does Changing Structure Matter? The American Political Science Review 74:999-1006.

Morgan, David R. and Sheilah S. Watson

1995 The Effects of Mayoral Power on Urban Fiscal Policy. Policy Studies Journal 23:231-243.

Neter, John, Michael H. Kutner, Chistopher J. Nachtsheim, and William Wasserman.

1996 Applied Linear Statisical Models, $4^{\text {th }}$ ed. Boston, MA: McGraw- Hill. 
Osgood, D. Wayne

2000 Poisson- Based Regression Analysis of Aggregate Crime Rates. Journal of Quantitative Criminology 16:21-43.

Osgood, D. Wayne, and Chambers

2000 Social Disorganization Outside the Metropolis: An Analysis of Rural Youth Violence. Criminology 38: 81-115.

Parker, Karen F. and Patricia L. McCall

1999 Structural Conditions and Racial Homicide Patterns: A Look at the Multiple Disadvantages in Urban Areas. Criminology 37:447-477.

Peterson, Ruth D., and Lauren J. Krivo

1993 Racial Segregation and Homicide. Social Forces 71:1001-1026.

Peterson, Ruth D., Lauren Krivo, and Mark A. Harris

2000 Disadvantage and Neighborhood Violent Crime: Do Local Institutions Matter? Journal of Research in Crime and Delinquency 37:31-63.

Rose, Dina R., and Todd R. Clear

1998 Incarceration, Social Capital, and Crime: Implications for Social Disorganization Theory. Criminology 36:441-479.

Rosenfeld, Richard, Steven F. Messner, and Eric Baumer

2001 Social Capital and Homicide. Social Forces 80: 283-309.

Salzstein, Grace Hall

1989 Black Mayors and Police Policies. Journal of Politics 51:525-544.

Sampson, Robert J.

1985 Race and Criminal Violence: A Demographically Disaggregated Analysis of Urban Homicide. Crime and Delinquency 31:47-82. 
1987 Urban Black Violence: The Effect of Male Joblessness and Family Disruption. American Journal of Sociology 93:348-382.

Sampson, Robert J. and Stephen W. Raudenbush

1999 Systemic Social Observation of Public Spaces: A New Look at Disorder in Urban Neighborhoods American Journal of Sociology 105:603-651.

Sampson, Robert J., Stephen Raudenbush, and Felton Earls

1997 Neighborhoods and Violent Crime: A Multilevel Study of Collective Efficacy. Science 277:918-924.

Santoro, Wayne A.

1995 Black Politics and Employment Policies: The Determinants of Local Government Affirmative Action. Social Science Quarterly. 76:795-806.

Sass, Tim R. and Stephen L. Mehay

1995 The Voting Rights Act, District Elections, and the Success of Black Candidates in Municipal Elections. The Journal of Law and Economics. 38:367-392.

Sass, Tim R. and Bobby J.Pittmann, Jr.

2000 The Changing Impact of Electoral Structure on Black Representation in the South, 19701996. Public Choice 104:369-388.

Savolainen, Jukka

2000 Inequality, Welfare State, and Homicide: Further Support for the Institutional Anomie Theory. Criminology 38: 1021-1043.

Sharp, Elaine B.

1991 Institutional Manifestations of Accessibility and Urban Economic Development Policy. The Western Political Quarterly 44:129-147. 
Shaw, Clifford R. and Henry D. Mckay

1972 Juvenile Delinquency and Urban Areas (Revised ed). Chicago: University of Chicago Press.

Shihadeh, Edward S., and Nicole Flynn

1996 Segregation and Crime: The Effects of Social Isolation on the Rates of Black Urban

Violence. Social Forces 74:325-352.

Shumaker, Paul and Russell W. Getter

1983 Structural Sources of Unequal Responsiveness to Group Demands in American Cities. The Western Political Quarterly 36:7-29.

Skogan, Wesley G. and Susan M. Hartnett.

1997 Community Policing, Chicago Style. New York: Oxford University Press.

Urban Data Service

1982 Municipal Form of Government- 1981. Survey Conducted by the International City Management Association, Washington, D.C.

1987 Municipal Form of Government- 1986. Survey Conducted by the International City Management Association, Washington, D.C.

1992 Municipal Form of Government- 1991. Survey Conducted by the International City Management Association, Washington, D.C.

1997 Municipal Form of Government- 1996. Survey Conducted by the International City Management Association, Washington, D.C.

U.S. Department of Commerce. Bureau of the Census

2000 County and City Data Book [United States], 1994 (computer file). Washington, D.C: US Dept. of Commerce, Bureau of the Census. Generated via University of Virginia website, <http://fisher.lib.virginia.edu/ccdb/city94.html 1994>; (02 August 2000).

U.S. Department of Justice, Federal Bureau of Investigation 
2000 Uniform Crime Reporting Program Data:1975-1997 [Offenses Known and Clearances by Arrest, various years] (Computer file). Compiled by the U.S. Dept. of Justice, Federal Bureau of Investigation. ICPSR ed. Ann Arbor, MI: Inter-university Consortium for Political and Social Research (producer and distributor), 2000.

Vedlitz, Arnold and Charles A. Johnson

1982 Community Racial Segregation, Electoral Structure and Minority Representation. Social Science Quarterly. 63:729-736.

Velez, Maria B.

2001 The Role of Public Social Control in Urban Neighborhoods: A Multi- Level Analysis of Victimization Risk. Criminology 39:837-863.

Welch, Susan

1990 The Impact of At-Large Elections on the Representation of Blacks and Hispanics. Journal of Politics 52:1050-1075.

Welch, Susan and Timothy Bledsoe

1986 The Partisan Consequences of Nonpartisan Elections and the Changing Nature of Urban Politics. American Journal of Political Science 30:128-139.

1988 Urban Reform and Its Consequences. Chicago, Ill: University of Chicago Press.

Wilson, James Q. and Barbara Boland

1978 The Effect of the Police on Crime. Law and Society Review 12:367-390.

Wong, Kenneth K

1988 Economic Constraint and Political Choice in Urban Policymaking. American Journal of Political Science 32:1-18. 
Zax, Jeffrey S.

1990 Election Methods and Black and Hispanic City Council Membership. Social Science Quarterly 71:339-355.

Zhao, Jihong

1996 Why Police Organizations Change: A Study of Community Oriented Policing. Washington, DC: Police Executive Research Forum. 
Table 1. Local Political Structures

CITY FORM OF GOVERNMENT

Mayor/ Council head of government is elected

Council/ City Manager head of government is appointed professional administrator

Commission group of elected officials collectively govern

ELECTORAL SYSTEM

District

council members elected based on geographical area within city

At-large all council members elected by whole city

Mixed some council members elected at large and others by district

PARTISANSHIP

Partisan

local or national political party appears on the ballot in general election

Non-Partisan

local or national political party does not appear on the ballot in general election 
Table 2. Negative Binomial Regression of City Violent Crime on Social Structure, Local Political Structures and Race of Elected Officials

\begin{tabular}{|c|c|c|c|c|}
\hline VARIABLE & Eq. (1) & $\underline{\text { Eq.(2) }}$ & Eq. (3) & Eq. (4) \\
\hline \multirow[t]{2}{*}{ Constant } & $-\overline{-8.0043} * * * *$ & $\overline{-8.0641} * * * *$ & $-7.9689 * * * *$ & $-8.0880^{* * * *}$ \\
\hline & $(0.1096)$ & $(0.1115)$ & $(0.1100)$ & $(0.1240)$ \\
\hline \multirow[t]{2}{*}{ Violent Crime Rate 1990} & $0.3558 * * * *$ & $0.3596^{* * * *}$ & $0.3572^{* * * *}$ & $0.3698^{* * * *}$ \\
\hline & $(0.0148)$ & $(0.0149)$ & $(0.0146)$ & $(0.0172)$ \\
\hline \multirow[t]{2}{*}{ Deprivation Index } & $0.2630 * * * *$ & $0.3094^{* * * *}$ & $0.3099 * * * *$ & $0.3249^{* * * *}$ \\
\hline & $(0.0214)$ & $(0.0243)$ & $(0.0263)$ & $(0.0299)$ \\
\hline \multirow[t]{2}{*}{ Percent Black (Ln) } & $0.1003 * * * *$ & $0.1139^{* * * *}$ & $0.1132^{* * * *}$ & $0.1085^{* * * *}$ \\
\hline & $(0.0129)$ & $(0.0132)$ & $(0.0130)$ & $(0.0161)$ \\
\hline \multirow[t]{2}{*}{ Percent Hispanic (Ln) } & $0.0645 * * * *$ & $0.0573^{* * * *}$ & $0.0570^{* * * *}$ & $0.0679^{* * * *}$ \\
\hline & $(0.0144)$ & $(0.0143)$ & $(0.0143)$ & $(0.0166)$ \\
\hline \multirow[t]{2}{*}{ Percent Foreign Born } & -0.0012 & -0.0036 & -0.0033 & -0.0044 \\
\hline & $(0.0023)$ & $(0.0023)$ & $(0.0023)$ & $(0.0027)$ \\
\hline \multirow[t]{2}{*}{ Percent Population Change } & -0.0001 & -0.0003 & -0.0003 & -0.0000 \\
\hline & $(0.0003)$ & $(0.0003)$ & $(0.0003)$ & $(0.0003)$ \\
\hline \multirow[t]{2}{*}{ Percent Age 18-24 (Ln) } & $-0.2522 * * * *$ & $-0.2756 * * * *$ & $-0.2718^{* * * *}$ & $-0.2523^{* * * *}$ \\
\hline & $(0.0422)$ & $(0.0421)$ & $(0.0420)$ & $(0.0468)$ \\
\hline \multirow[t]{2}{*}{ Population Density } & -0.0011 & -0.0008 & -0.0008 & -0.0004 \\
\hline & $(0.0006)$ & $(0.0006)$ & $(0.0006)$ & $(0.0008)$ \\
\hline \multirow[t]{2}{*}{ South } & $0.0851 *$ & 0.0573 & 0.0556 & 0.0683 \\
\hline & $(0.0363)$ & $(0.0365)$ & $(0.0364)$ & $(0.0422)$ \\
\hline \multirow[t]{2}{*}{ Police Spending } & $0.1427 * * * *$ & $0.1260 * * * *$ & $0.1269 * * * *$ & $0.1724^{* * * *}$ \\
\hline & $(0.0328)$ & $(0.0320)$ & $(0.0323)$ & $(0.0363)$ \\
\hline \multirow[t]{2}{*}{ City Expenditures } & $-0.1180^{* * * *}$ & $-0.1048^{* * *}$ & $-0.1003^{* * *}$ & $-0.1001 * *$ \\
\hline & $(0.0281)$ & $(0.0279)$ & $(0.0280)$ & $(0.0339)$ \\
\hline \multicolumn{5}{|l|}{ Local Political Structures } \\
\hline \multirow[t]{2}{*}{ Mayor/ Council } & & -0.0453 & & \\
\hline & & $(0.0317)$ & & \\
\hline \multirow[t]{2}{*}{ Partisan } & & -0.0606 & & \\
\hline & & $(0.0374)$ & & \\
\hline \multirow[t]{2}{*}{ At-Large } & & $0.0801^{* *}$ & & \\
\hline & & $(0.0304)$ & & \\
\hline \multirow[t]{2}{*}{ Deprivation*Mayor/ Council } & & $-0.0957 * *$ & & \\
\hline & & $(0.0296)$ & & \\
\hline \multirow[t]{2}{*}{ Traditional Govt. Structures Index } & & & $-0.0628 * * * *$ & $-0.0575 * *$ \\
\hline & & & $(0.0154)$ & $(0.0179)$ \\
\hline Deprivation*Traditional & & & $-0.0343^{*}$ & $-0.0609 * * *$ \\
\hline & & & $(0.0138)$ & $(0.0177)$ \\
\hline \multicolumn{5}{|l|}{ Black Elected Officials } \\
\hline \multirow[t]{2}{*}{ Black Council Proportion } & & & & -0.1010 \\
\hline & & & & (0.1777) \\
\hline \multirow[t]{2}{*}{ Black Mayor } & & & & $-0.1871^{*}$ \\
\hline & & & & $(0.0864)$ \\
\hline $\mathrm{N}$ & 958 & 958 & 958 & 722 \\
\hline Log- Likelihood & 10661091.4 & 10661105.5 & 10661103.2 & 5165258.9 \\
\hline Likelihood Ratio $X^{2 a}$ & $1491.4^{* * * *}$ & $28.2^{* * *}$ & $23.6^{* * *}$ & $4.63^{+}$ \\
\hline
\end{tabular}

Note: Standard errors in parentheses, ${ }^{+} \mathrm{p}<.10,{ }^{*} \mathrm{p}<.05$, ${ }^{* *} \mathrm{p}<.01,{ }^{* * *} \mathrm{p}<.001,{ }^{* * * *} \mathrm{p}<.0001$ (2-tailed tests).

$a \mathrm{X}^{2}$ in equation 1 refers to LR comparison with intercept only model, $\mathrm{X}^{2}$ in equations 2 and 3 refer to LR comparison with equation $1, X^{2}$ in equation 4 refers to LR comparison with equation 3 model with $\mathrm{N}$ of 722. 


\section{Appendix A. Summary Of ICMA FOG Survey Questions Used To Construct Local Institutional Political Variables}

\section{MAYOR/ COUNCIL}

Question 1: Indicate your current form of government as defined by your charter, ordinance, or state law.

1. Mayor/ Council

2. Council/ Manager

3. Commission

4. Town Meeting

5. Representative Town Meeting

\section{DISTRICT}

Question 29: Indicate the number of council members selected by each of the following methods?

1. Nominated and elected at large

2. Nominated by ward or district and elected at large

3. Nominated by ward or district and elected by ward or district

4. Other

a. Total council members listed in $1-4$.

\section{PARTISAN}

Question 21: Does the political party affiliation of candidates for board or council appear on the ballot in a local general election?

1. No 2. Yes 
Appendix B. Univariate Statistics for Variables Reported in Table 2.

\begin{tabular}{|c|c|c|c|c|c|}
\hline & $\mathrm{N}$ & Mean & Std Dev. & Min. & Max. \\
\hline Violent Crime 91 & 958 & 796.11 & 691.84 & 2.33 & 4301.0 \\
\hline Violent Crime 90 & 958 & 762.51 & 684.75 & 21.96 & 4353.0 \\
\hline Population & 958 & 104183 & 304946 & 25001 & 7322564 \\
\hline Population Density & 958 & 3784.0 & 3202.0 & 11.0 & 44043.0 \\
\hline Percent 18-24 & 958 & 12.39 & 6.64 & 5.10 & 65.6 \\
\hline Police Exp/ Resident & 958 & 11.68 & 5.29 & 3.28 & 75.16 \\
\hline City Exp/ Capita & 958 & 874.55 & 565.08 & 161.00 & 7154.00 \\
\hline Percent Black & 958 & 11.99 & 15.31 & 0.08 & 89.95 \\
\hline Percent Hispanic & 958 & 10.42 & 15.15 & 0.20 & 93.9 \\
\hline Deprivation Index & 958 & 0.007 & 0.972 & -2.11 & 3.617 \\
\hline $\begin{array}{l}\text { Pct. Owner } \\
\text { Occupied Homes }\end{array}$ & 958 & 57.79 & 12.54 & 21.63 & 91.54 \\
\hline Percent Poor & 958 & 12.72 & 7.38 & 1.11 & 43.20 \\
\hline Percent Unemployed & 958 & 6.46 & 2.66 & 1.90 & 19.70 \\
\hline $\begin{array}{l}\text { Pct. Female Headed } \\
\text { Households }\end{array}$ & 958 & 18.16 & 6.92 & 5.61 & 51.72 \\
\hline $\begin{array}{l}\text { Pct. Population } \\
\text { Change }\end{array}$ & 958 & 23.38 & 47.13 & -23.20 & 587.70 \\
\hline Pct. Foreign Born & 958 & 9.26 & 9.78 & 0.20 & 70.40 \\
\hline $\begin{array}{l}\text { Black City Council } \\
\text { Prop. }\end{array}$ & 722 & 0.081 & 0.13 & 0 & .75 \\
\hline
\end{tabular}


Appendix C. Bivariate Correlation Matrix*

\begin{tabular}{|c|c|c|c|c|c|c|c|c|c|c|}
\hline & 1 & 2 & 3 & 4 & 5 & 6 & 7 & 8 & 9 & 10 \\
\hline $\begin{array}{l}\text { 1. Violent } \\
\text { Crime } 91\end{array}$ & 1.00 & & & & & & & & & \\
\hline $\begin{array}{l}\text { 2. Violent } \\
\text { Crime } 90\end{array}$ & $.94 *$ & 1.00 & & & & & & & & \\
\hline 3. Population & $.26^{*}$ & $.25 *$ & 1.00 & & & & & & & \\
\hline $\begin{array}{l}\text { 4. Population } \\
\text { Density }\end{array}$ & $.21^{*}$ & $.23^{*}$ & $.24 *$ & 1.00 & & & & & & \\
\hline 5. \% 18-24 & -.02 & -.02 & -.01 & .02 & 1.00 & & & & & \\
\hline $\begin{array}{l}\text { 6. Police } \\
\text { Expenditures }\end{array}$ & $.39 *$ & .41 & $.19 *$ & $.27 *$ & -.10 & 1.00 & & & & \\
\hline $\begin{array}{l}\text { 7.Expend/ } \\
\text { Capita }\end{array}$ & $.24^{*}$ & $.25 *$ & $.27 *$ & $.15^{*}$ & -.01 & $.49 *$ & 1.00 & & & \\
\hline 8. Percent Black & $.66^{*}$ & $.67 *$ & $.15^{*}$ & $.08 *$ & .04 & $.23 *$ & $.22 *$ & 1.00 & & \\
\hline $\begin{array}{l}\text { 9. Percent } \\
\text { Hispanic }\end{array}$ & $.22 *$ & $.22 *$ & $.09 *$ & $.41^{*}$ & -.02 & $.13^{*}$ & $-.06^{*}$ & $-.11^{*}$ & 1.00 & \\
\hline $\begin{array}{l}\text { 10. Depriv. } \\
\text { Index }\end{array}$ & $.66^{*}$ & $.65^{*}$ & $.17 *$ & $.25 *$ & $.32 *$ & $.17^{*}$ & $.23^{*}$ & $.63 *$ & $.25^{*}$ & 1.00 \\
\hline $\begin{array}{l}\text { 11. \% Own- Occ. } \\
\text { Homes }\end{array}$ & $-.4 *$ & $-.39 *$ & $-.16^{*}$ & $-.38 *$ & $-.51^{*}$ & $-.25 *$ & $-.31 *$ & $-.31 *$ & $-.23^{*}$ & $-.73^{*}$ \\
\hline 12. Percent Poor & $.54^{*}$ & $.53 *$ & $.12 *$ & .06 & $.42 *$ & .03 & $.08 *$ & $.52 *$ & $.24 *$ & $.91^{*}$ \\
\hline $\begin{array}{l}\text { 13. Percent } \\
\text { Unemployed }\end{array}$ & $.56^{*}$ & $.56^{*}$ & $.12 *$ & $.19 *$ & $.1^{*}$ & .05 & $.10^{*}$ & $.5 *$ & $.33^{*}$ & $.87^{*}$ \\
\hline $\begin{array}{l}\text { 14. Pct Female } \\
\text { Head House. }\end{array}$ & $.72 *$ & $.71^{*}$ & $.18^{*}$ & $.25 *$ & $.11^{*}$ & $.27 *$ & $.33 *$ & $.8 *$ & $.07 *$ & $.9 *$ \\
\hline $\begin{array}{l}\text { 15. \% Pop. } \\
\text { Chg }\end{array}$ & $-.15^{*}$ & $-.13^{*}$ & -.05 & $.17 *$ & $-.09 *$ & $-.11 *$ & $-.12 *$ & $-.20 *$ & $.12 *$ & $-.28 *$ \\
\hline $\begin{array}{l}\text { 16. \% Foreign } \\
\text { Born }\end{array}$ & $.14^{*}$ & $.17^{*}$ & $.12 *$ & $.62 *$ & $-.02 *$ & $.34^{*}$ & .04 & $-.13^{*}$ & $.74^{*}$ & $.07 *$ \\
\hline $\begin{array}{l}\text { 17. Traditional } \\
\text { Govt. Index }\end{array}$ & $.13^{*}$ & $.11^{*}$ & $.14 *$ & -.01 & .06 & $-.07 *$ & $.15^{*}$ & $.30 *$ & $-.27 *$ & $.25^{*}$ \\
\hline $\begin{array}{l}\text { 18. Black City } \\
\text { Council Prop. }\end{array}$ & $.57 *$ & $.59 *$ & $.17 *$ & .07 & .07 & $.17 *$ & $.20 *$ & $.83 *$ & $-.08 *$ & $.54^{*}$ \\
\hline 19. Black Mayor & $.39 *$ & $.4^{*}$ & $.26^{*}$ & $.17 *$ & .05 & $.2 *$ & $.17 *$ & $.40 *$ & .05 & $.32 *$ \\
\hline
\end{tabular}

* $\mathrm{p}<.05$ (two-tailed test), $\mathrm{N}=958$ for all variables except Black City Council Proportion and Black Mayor $(\mathrm{N}=722)$. 
Appendix C. Bivariate Correlation Matrix continued*

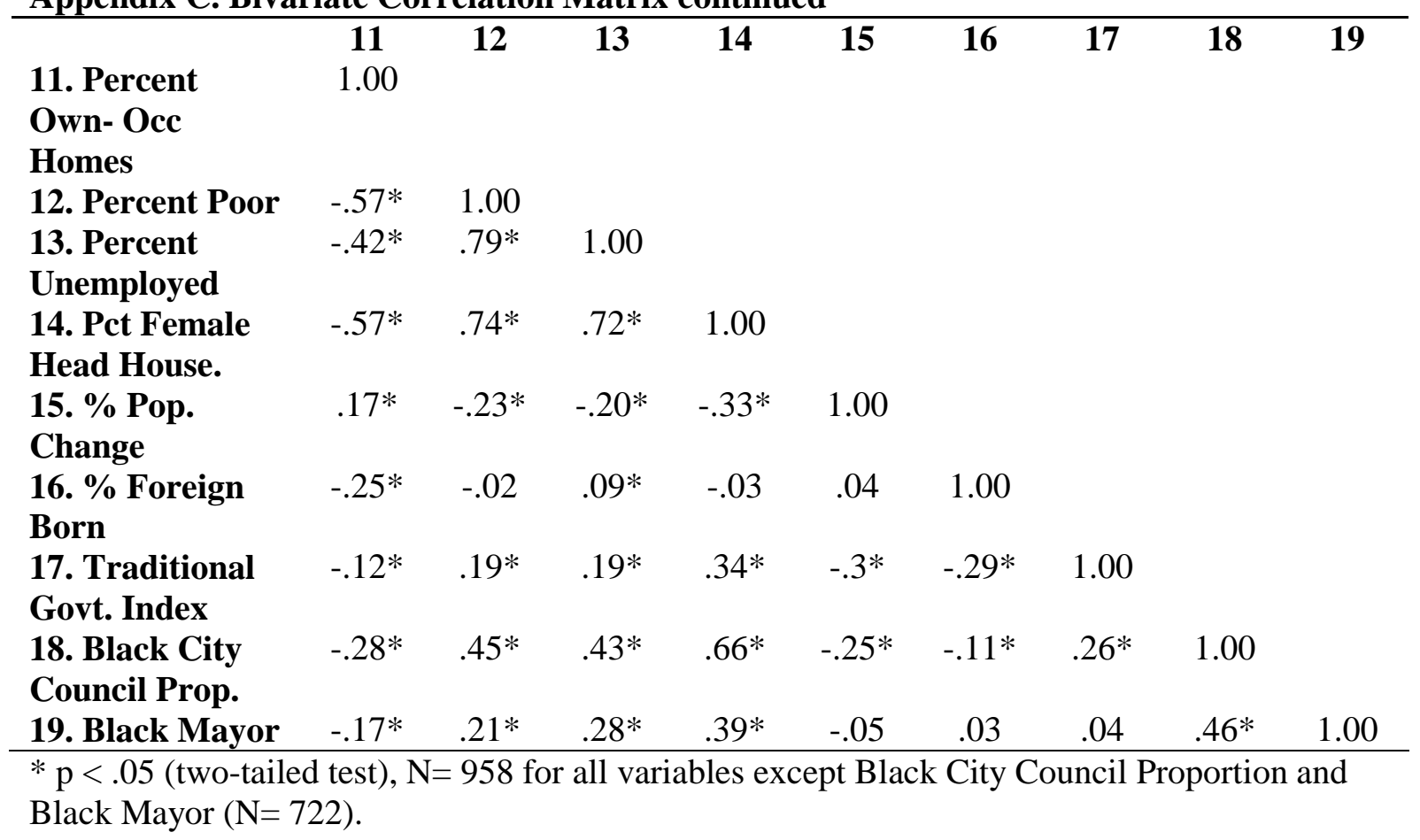

